\title{
The mediating effect of leverage and dividend policy on the influence of corporate governance towards firm value
}

\author{
Noorlailie Soewarno ${ }^{1, *}$ and Stephanie Yulia Arifin ${ }^{1}$ Bambang Tjahjadi ${ }^{1}$ \\ ${ }^{1}$ Universitas Airlangga, Indonesia
}

\begin{abstract}
This study examines the mediating effect of leverage and dividend policy on the influence of corporate governance towards firm value. This is a quantitative study used secondary data of 181 companies listed on the Indonesian Stock Exchange (IDX) in the year of 2014. The results showed that leverage did not mediate corporate governance-firm value relationship, and devidend policy partially mediated corporate governance-firm value relationship
\end{abstract}

\section{Introduction}

In 2002, the importance of corporate governance became more obvious as a series of corporate disasters such as frauds and meltdowns led to a series of bankruptcy filings after the 1998 economic crisis, included Enron and WorldCom)[1].

When a company is required to improve their performance quality through implementation of corporate governance, many steps have to be taken as form of responsibility to investors and creditors. Some of them are dividend distribution, controlling level of debt and repayment of principal loan amount and interest expense. The more payment for loan means lower return for shareholders. It is parallel with the findings of Hastori et al. [2], which said that there was a significantly negative relation between dividend payout policy and agency costs while leverage had significantly positive influence towards agency cost. Agency problem may occur when dividend paid is smaller because of higher payment for loan or higher amount of retained earnings. Many studies have been conducted to examine the relationship between corporate governance, leverage, dividend policy and firm value. Ionescu [3] argued that conducting corporate governance practices could transmit credible signal to investors. Appropriate corporate governance implementation could reduce the risk of managers' misbehaviors. Therefore, it can be assumed that there was significant positive connection between quality of corporate governance and firm value.

When investors feel ensured that their investment is profitable and information given is transparent, firms can be indicated as having high level of credibility. The trust of investors, then, can increase the attractiveness of a firm in stock market which leads to increase in firm value. Furthermore, there were still inconsistency in the results of previous studies. Therefore the influences are still required to be reexamined. Also, there was no research that tried to combine corporate governance, leverage, dividend policy and firm value all

\footnotetext{
*Corresponding author_noorlailie@gmail.com
} 
together. Therefore, the author is interested to study those relationships in Indonesian case. The purpose of this research was to investigate the existence of a significant direct and/or indirect influence of corporate governance, leverage and dividend policy towards firm value in companies listed in Indonesia Stock Exchange (IDX).

\section{Literature review}

In the agency theory, agents who tend to fulfill their own interest, tend to act recklessly by investing in low or even negative present value project using excessive external funding. This harmful activity can cause asymmetry information between agents and principals in terms of segregation of functions between ownership and management. This agency problem indicates that firm value will increase if principals regulate agent's behaviors in managing resources. Several previous studies found that the relationships between corporate governance and firm value varied. Board size and institutional shareholders were found that they influenced firm value positively while other indicators did negatively [4]. If the indicators are combined, corporate governance still has significant and positive connection with firm value [5]. Corporate governance can transmit strong signal to convince investors about companies' credibility, meaning that corporate governance contributes to increasing firm value [3] [6].

Previous studies investigating the relationship between corporate governance and leverage found that corporate governance was related negatively with the level of leverage [7] [8] [9]. This happened because if the company improved its corporate governance practices, management would eventually consider debt as disciplining device. Corporate governance will direct management only to take appropriate possible actions [10]. In the other hand, it was also found that corporate governance could increase the level of leverage because it expanded its credit-access [11]. Companies which have more independent directors has more long-term debt [12]. There is a positive and significant relationship between debt and firm value in countries with double taxation system but not in countries with imputation system [13]. The difference in those relationships depends on corporate tax rate and personal tax rate which reduces the tax advantage coming from corporate borrowing [14]. On the contrary, leverage also can influence firm value negatively [15]. The company which wants to increase firm value should only take leverage up to the optimum point because after that point, leverage will bring more cost than benefit [16].

H1: Leverage mediates the influence of corporate governance towards firm value

The relationship between corporate governance and dividend policy may differ depending upon the access of interest-bearing debt [17]. In South Africa, Kenya and Ghana, it was found that there was positive relationship between corporate governance and dividend payout as the other researches [18][19], while in Nigeria, corporate governance was linked negatively to dividend payout. Companies in Nigeria tended to reduce the cost of debt [17]. Regarding dividend policy and firm value, dividend per share and dividend yield are both factors in determining share prices [20]. Dividend per share has significant and positive relation with firm value while dividend yield has significant and negative relationship with firm value [20]. Dividends have positive information that earnings and other variable do not [15]. Investors in countries with poor investor protection will prefer dividends more because private benefits are more likely to happen [21]. Indonesia itself is considered as having poor legality, shareholder rights, and judicial efficiency compared with 13 other countries with emerging markets [7]. Conversely, it was found that dividend 
yield influenced shares prices negatively but dividend payout sometimes gave positive influence [22]. Dividend policy may have clientele effect on investors [20].

H2: Devidend policy mediates the influence of corporate governance towards firm value

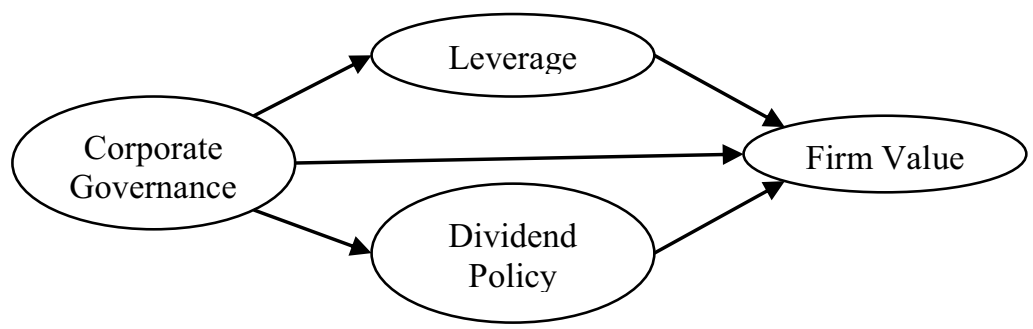

Figure 1 Conceptual Framework

\section{Research method}

The sample used in this study are companies listed in the Indonesia Stock Exchange (IDX) in the year of 2014, which are amounted to 181 companies. The data used is the secondary data which is financial data from financial statements of companies listed in IDX for the period which ended on December 31, 2014, dividends paid during 2014 and shares prices on April 30, 2015. The data was processed using the Partial Least Square (PLS) Warp. The following table elaborates indicators and operational definition of variables:

Table 1 Operational Definition of Variables

\begin{tabular}{|c|c|c|c|}
\hline Variables & Symbol & Indicators & Definition \\
\hline \multirow{3}{*}{$\begin{array}{c}\text { Corporate } \\
\text { Governance } \\
\text { (CG) }\end{array}$} & BS & Board size & $\begin{array}{l}\text { The number of members in board of } \\
\text { commissioners }\end{array}$ \\
\hline & $\mathrm{AC}$ & $\begin{array}{l}\text { Audit } \\
\text { committee }\end{array}$ & $\begin{array}{l}\text { The number of members in audit committee of a } \\
\text { company }\end{array}$ \\
\hline & AQ & $\begin{array}{l}\text { Audit } \\
\text { quality }\end{array}$ & $\begin{array}{l}\text { Whether a company using big four public } \\
\text { company or not, measured by a scale of } 1 \text { for } \\
\text { companies using big-four public accounting firm } \\
\text { and } 0 \text { for companies using non-big-four public } \\
\text { accounting firm }\end{array}$ \\
\hline \multirow[b]{2}{*}{ Firm value $(\mathrm{FV})$} & $\mathrm{Q}$ & Tobin's Q & $($ Market value of equity + debt)/Assets \\
\hline & PBV & $\begin{array}{l}\text { Price to } \\
\text { book value }\end{array}$ & (Market value per share)/Book value per share \\
\hline \multirow{2}{*}{ Leverage (Lev) } & $\mathrm{D} / \mathrm{E}$ & $\begin{array}{l}\text { Debt to } \\
\text { equity ratio }\end{array}$ & Total debt/Total equity \\
\hline & $\mathrm{D} / \mathrm{A}$ & $\begin{array}{l}\text { Debt to } \\
\text { assets ratio }\end{array}$ & Total debt/Total assets \\
\hline \multirow{2}{*}{$\begin{array}{l}\text { Dividend Policy } \\
\text { (Div) }\end{array}$} & DPR & $\begin{array}{l}\text { Dividend } \\
\text { payout ratio }\end{array}$ & Dividend per share/ Earnings per share \\
\hline & DY & $\begin{array}{l}\text { Dividend } \\
\text { yield }\end{array}$ & Dividend per share/ Price per share \\
\hline
\end{tabular}




\section{Results and discussion}

\subsection{Direct influences}

Table 2 Direct Influences

\begin{tabular}{|c|c|c|l|}
\hline Direct Relationship & B-value & P-value & Conclusion \\
\hline $\mathrm{CG} \rightarrow$ Lev & 0.26 & $<0.01$ & Accepted \\
\hline $\mathrm{CG} \rightarrow$ Div & 0.28 & $<0.01$ & Accepted \\
\hline $\mathrm{CG} \rightarrow$ FV & 0.18 & $<0.01$ & Accepted \\
\hline Lev $\rightarrow$ FV & -0.17 & $<0.01$ & Accepted \\
\hline $\mathrm{Div} \rightarrow \mathrm{FV}$ & 0.21 & $<0.01$ & Accepted \\
\hline
\end{tabular}

Corporate governance is found to have positive and significant impact on leverage. Corporate governance can increase the creditors' trust so that the credit access will be higher, the level of leverage increases and cost of debt decreases [11]. This can happen because higher level of CG make a company able to have more long-term financing [12]. By reducing agency problems, corporate governance, then, will increase the trust of creditors about the optimal condition of the company which lead to increase in leverage.

Corporate governance positively and significantly correlate to dividend policy. By improving corporate governance, a firm can increase the minorities' right which led to increase in dividend policy. The empirical finding shows that corporate governance influences dividend policy positively. Corporate governance can protect minorities' right in dividend policy [18]. Thus, higher level of corporate governance means higher dividend policy.

Corporate governance also has positive impact on firm value. Companies in countries with weak legal protection system, including Indonesia, can increase their credibility by improving their Corporate governance because it signals about investor protection and asymmetric information reduction [3][6]. Corporate governance can solve agency problems. Having more transparent information and good relationship can assure the investors about the credibility of a firm.

This study showed that leverage affects firm value negatively, and supported study the previous study by [15] [16]. Leverage can increase firm value until certain point [16]. After it is reached, the increase of leverage will influence negatively towards firm value. The increase experienced by firm value until the maximum point is caused by the existence of leverage which brings more tax benefit than cost of debt. When the cost of debt is higher than the benefit, firm value will decline because the investors feel that the investment is too risky. Thus, firm value will increase until certain point then there is a decline.

In the agency theory, it is explained that the interest of shareholders is to gain more return while the interest of management is to retain or have private benefit. By sharing part of profits as dividends, investors can consider that the firm has minorities' right which lead to increase in firm value. This research also found that dividend policy positively influence firm value. Investors in countries with poor investor protection (such as Indonesia) will prefer dividends more because private benefits are more likely to happen [21]. 


\subsection{The mediating effects of leverage on corporate governance-firm value relationship}

Figure 2 showed the empirical result of the direct effect of corporate governance on firm value. It showed that $p$-value $<.01$ with the beta value of 0.18 .

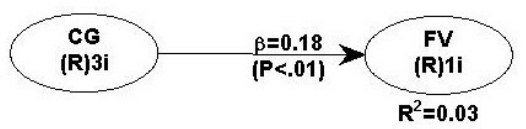

Figure 2. Direct Effect of Corporate Governance on Firm Value

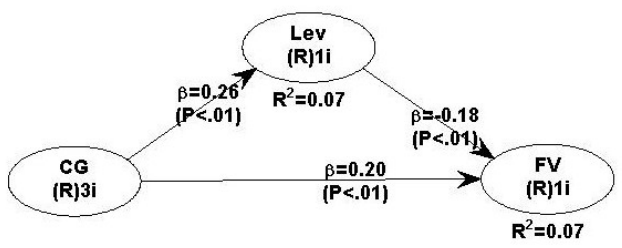

Figure 3. The Mediating Effect of Leverage on Corporate Governance-Firm Value Relationship

Figure 3 showed that the direct effect was still significant (p-value $<.01$ ), but the beta value increased from 0.18 to 0.20 . This was not a sign for the existence of mediating effect. Therefore the hypothesis 1 stating that leverage mediates the influence of corporate governance towards firm value cannot be accepted. Ensuring that management takes the best action to create long-term and sustainable value is a main topic in agency theory. By having corporate governance, a firm can signal to investors about its credibility. Besides, corporate governance also can increase the transparency of a firm. Transparency can reduce the asymmetric information between management and investors. Corporate governance has already influenced firm value, whether the companies have high or lower leverage. Corporate governance can signal to investors about investors' protection and reduction of asymmetric information through fulfilling their transparency obligations [3] [6]. Corporate governance influences leverage positively [11] [12]. By implementing and improving corporate governance, a company can increase the confidence of creditors, hence increasing the leverage level too. Higher leverage means higher risk, and at the same time can potentially lower firm value. Decreasing firm value is caused by uneasy investors of higher risk. Even though debt brings tax benefit; it also brings higher risks for investors, such as bankruptcy costs [15].

\subsection{The mediating effects of devidend policy on corporate governance-firm value relationship}

Figure 4 showed that the direct effect was still significant (p-value is more than $1 \%$, but still less than $5 \%$ ), and the beta value decreased from 0.18 to 0.14 . This was a sign for the existence of partial mediation effect. Therefore the hypothesis 2 stating that dividend policy mediates the influence of corporate governance towards firm value can be accepted. 


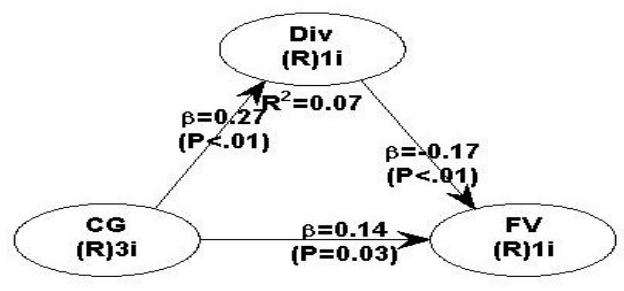

Figure 4. The Mediating Effect of Devidend Policy on Corporate Governance-Firm Value Relationship

In countries with weak legal protection system, corporate governance could enhance credible investor protection signal and reduce asymmetric information [5] [16]. Corporate governance could increase the right of minorities to obtain their dividend which meant higher corporate governance showed higher dividend policy [19]. The investors will feel safer about their dividend rights of minorities if companies have corporate governance. The trust of investors, then eventually will increase firm value.

\section{Conclusion and suggestions}

The focus of this study is to examine the mediating effects of leverage and dividend policy on corporate governance-firm value relationship in the Indonesian stock Exchange (IDX). Empirical findings showed the following results. Firstly, leverage did not mediate the influence of corporate governance towards firm value. Secondly, dividend policy mediated the relationship between corporate governance and firm value. Further research should expand into industrial sectors and/or using a longer period and using different indicator for each variable. For the practitioners, it is better to improve corporate governance, keep the leverage low and watching the effects of dividend policy towards firm value.

\section{References}

1. Monks, Robert A. G. and Nell Minow. Corporate Governance. New Jersey: WileyBlackwell (2004)

2. Hastori, Hermanto Siregar, et al. Agency Costs, Corporate Governance and Ownership Concentration: The Case of Agro-industrial Companies in Indonesia. Asian Social Science, 11(18): 311-319 (2015)

3. Ionescu, Luminita. Effects of Corporate Governance on Firm Value. Economics, Management, and Financial Markets, 7(4), 215-220 (2012)

4. Marouan, Kouki and Dabboussi Moez. Impact of Corporate Governance on Shareholder Value Creation: Evidence from Tunisian Context. International Business Research, 8(5) (2015)

5. Siahaan, Fadjar O.P. The Effect of Good Corporate Governance Mechanism, Leverage, and Firm Size on Firm Value. GTSF International Journal on Business Review (GBR), 2(4):137-142 (2013)

6. Klapper, Leora F. and Inessa Love. Corporate Governance, Investor Protection, and Performance in Emerging Markets. World Bank Policy Research Working Paper (2002) 
7. Bunkanwanicha et al., (2008)

8. Arping, Stefan and Zacharias Sautner. Corporate Governance and Leverage: Evidence from a Natural Experiment. Tinbergen Institute Discussion Paper, 10-019/2 (2010)

9. Richardson, Grant, et al. Corporate Tax Aggressiveness, Outside Directors and Debt Policy: An empirical Analysis. Journal of Corporate Finance, 25:107-121 (2014)

10. Saad, Noriza Mohd. Corporate Governance Compliance and the Effects to Capital Structure in Malaysia. International Journal of Economic and Finance, 2(1): 105-114 (2010)

11. Funchal, Bruno and Daniel Gottlieb. Corporate Governance, Bankruptcy Law and Firms' Debt Financing Under Uncertainty. Corporate Ownership and Control, 6(2):4750 (2008)

12. Alves, Paulo, E.B. Couto, and P.M. Francisco. Board of Director Composition and Capital Stucture. Research in International Business and Finance, 35, 1-32 (2015)

13. Jiang, Yuanyuan. Taxes, Debt, and Firm Value: New Evidence. Yale University, ProQuest Dissertations Publishing (2004)

14. Myers, Steward C. Determinats of Corporate Borrowing. Journal of Financial Economics, 5: 147-175 (1977)

15. Fama, Eugene F. and Kenneth R. French. Taxes, Financing decisions, and Firm Value, (1977). (Online), (https:/ssrn.com/abstract=1871 accessed on Oct. 13 (2015)

16. Modigliani, Franco and Merton H. Miller. Corporate Income Taxes and the Cost of Capital: A Correction. The American Economic Review, 53(3) (1963)

17. Abor, Joshua and Vera Viador. Does Corporate Governance Explain Dividend Policy in Sub-Saharan Africa? International Journal of Law and Management, 55(3):201-225 (2013)

18. Kowalewski, Oskar, I. Stetsyuk, and O. Talavera. Corporate Governance and Dividend Policy in Poland. German Istitute of Economic Research, 702 (July).German Institutte for Economic research, 702 (July) (2007)

19. Schellenger, Michael H., D. D. Wood, and A. Tashakori. Board of Director Composition, Shareholder Wealth and Dividend Policy. Journal of Management, 15(3):457-467 (1989)

20. Sharif, Taimur, H. Purohit, and R. Pillai. Analysis of Factors Affecting Share Prices: The Case of Bahrain Stock Exchange. International Journal of Economics and Finance, 7(3):207-216 (2015)

21. Pinkowitz, Lee, R. Stulz, and R. Williamson. Does the Contribution of Corporate Cash Holdings and Dividends to Firm Value Depend on Governance: A Cross-country Analysis. The Journal of Finance, 61(6):2725-2751 (2006)

22. Okafor, C. A. and C. O. Mgbame. Dividend Policy and Share Price Volatility in Nigeria. Jorind (9)1 June 2011:202-210 (2011) 